\title{
Effect of Different Crop Regulation Methods and Chemicals on Growth, Flowering and Yield of Guava cv. Arka Mridula
}

\author{
P. Mishra ${ }^{1}$, G. Mandal ${ }^{2}$ and R. K. Tarai ${ }^{3 *}$ \\ ${ }^{1}$ College of Horticulture Krishi Vigyan Kendra, Kendrapara, OUAT, India \\ ${ }^{2}$ College of Horticulture Visva-Bharati, Sriniketan, India \\ ${ }^{3}$ College of Horticulture, Chiplima, OUAT, India \\ *Corresponding author
}

\section{A B S T R A C T}

\begin{abstract}
A field experiment was conducted during 2016-17 and 2017-18 at Instructional Farm, Krishi Vigyan Kendra, Jharsuguda in Guava (Psidium guajava L.)" with an objective to evaluate the effect of plant growth regulation practices (both cultural and chemical methods) on vegetative growth, flowering and yield. The soil of the experimental orchard is red laterite and the climatic condition of the region is sub-tropical dry climate having hot and dry summer and mild winter. The experiment consisted of 8 treatments viz., $\mathrm{T}_{1}:$ Control, $\mathrm{T}_{2}$ : Shoot bending; $\mathrm{T}_{3}: 10 \mathrm{~cm}$ pruning with complete removal of old leaves, in April-May ; $\mathrm{T}_{4}: 50 \%$ fruit thinning randomly by hand at an average fruit weight $15-20 \mathrm{~g}$ in April-May ; $\mathrm{T}_{5}$ : Foliar spray of Naphthalene Acetamide (NAD) @ $50 \mathrm{ppm}$ twice at 15 days interval during April-May ; $\mathrm{T}_{6}$ : Foliar spray of $(2,4-\mathrm{D}) @ 60$ ppm, twice at 15 days interval in the during April-May; $\mathrm{T}_{7}$ : Foliar spray of urea @ 15\%, twice at 15 days interval during April-May and $\mathrm{T}_{8}$ : Foliar spray of Dinitro Ortho Cresol (DNOC) @ 10ppm, twice at 10 days during April-May. These 8 treatments were evaluated in randomized block design with three replications. From the experiment, it was found that untreated treatment (Control i.e. $\mathrm{T}_{1}$ ) resulted tallest plant while minimum plant height was recorded in Bending $\left(\mathrm{T}_{2}\right)$. The canopy spread in East-West and NorthSouth were recorded highest in $\mathrm{T}_{3}(10 \mathrm{~cm}$ pruning). Number of days required for emergence of new shoot was recorded minimum of (18.00 \& 19.2 days) shoot bending $\left(\mathrm{T}_{2}\right)$ and $10 \mathrm{~cm}$ pruning $\left(\mathrm{T}_{3}\right)$ respectively while it was highest (35.8 days) in the untreated control $\left(\mathrm{T}_{1}\right)$. Shoot bending $\left(\mathrm{T}_{2}\right)$ treatment took minimum days (43.5 days) while control plants $\left(\mathrm{T}_{1}\right)$ took maximum days (50.5days) for initiation of flowers in the new shoots. The period required for fruit maturity varied from 126.7 days in bending $\left(\mathrm{T}_{2}\right)$ to 134.5 days in control plants $\left(\mathrm{T}_{1}\right)$. Shoot bending $\left(\mathrm{T}_{2}\right)$ recorded highest number of fruits per plant during both the years and were significantly different from other treatments. From the mean data heaviest fruit (133.6 g) was obtained in $\mathrm{T}_{5}(50 \mathrm{ppm}$ NAD) followed by in $129.7 \mathrm{~g}$ in $\mathrm{T}_{3}(10 \mathrm{~cm}$ pruning $)$ and $129.2 \mathrm{~g} \mathrm{~T}_{6}(60 \mathrm{ppm} 2,4-\mathrm{D})$ whereas lowest fruit weight was obtained in control $(88 \mathrm{~g})$. Similarly, $50 \mathrm{ppm}$ NAD $\left(\mathrm{T}_{5}\right)$ gave highest fruit yield $(8.80 \mathrm{~kg} / \mathrm{plant})$ closely followed by in $\mathrm{T}_{3}(10 \mathrm{~cm}$ pruning $)$ with a yield of $7.88 \mathrm{~kg} / \mathrm{plant}$. The lowest yield was recorded in control $(5.43 \mathrm{~kg} / \mathrm{plant})$.
\end{abstract}

\section{Keywords}

Guava, Bending,

Pruning, Thining,

Chemicals, Growth,

Flowering, Yield

\section{Article Info}

Accepted:

07 November 2020

Available Online:

10 December 2020

\section{Introduction}

Guava is a popular fruit tree of tropical and sub-tropical climate and is native to the Tropical America. It is contributing $4.1 \%$ to the total fruit production in India. The crop covers about 2.60 lakh hectare area of the country with an annual production of 38.26 lakh tonnes with an average productivity of 14.75 metric tonnes per hectare (Anon, 
2017).It is the third richest source of Vitamin C $(299 \mathrm{mg} / 100 \mathrm{~g})$ after Barbados cherry (1000-4000 mg/100 g pulp) and aonla (600 $\mathrm{mg} / 100 \mathrm{~g}$ of pulp) contains 2 to 5 times more vitamin $\mathrm{C}$ than oranges and 10 times more than tomato Gupta (2014). Guava bears fruit on current season's shoot and flowers appear in solitary or in cymes of two or three in the axil of leaves.Crop regulation in guava can be adopted successfully by various cultural and chemical methods. In general, guava flowers twice in a year, i.e., in April-May and August-September, of which fruits ripen in rainy and winter season, respectively. The fruits produced in rainy season are insipid and watery and do not keep well. Fruits of winter season crop are superior in all respect as compared to rainy season fruits (Sahoo and Tarai, 2018). Therefore there is need to regulate guava crop in such a way that only quality fruits are harvested in winter season (Gorakh and Reddy, 1997). The basic theory of crop regulation is to manipulate the natural flowering and fruiting of guava plant in desired season of the year that put in to better fruit yield, quality, profitability and sustainability of the environment by reducing the use of the frequency of the pesticides. This concept is based on the fact that guava flowers are borne only on new, succulent, vigorously emerging vegetative growths. Crop regulation in guava can be adopted successfully by various cultural and chemical methods. Most of the research were already carried out in guava with an objective to reduce rainy season crop and to get more winter season crop by means of root exposure and root pruning, shoot pruning, mechanical flower thinning and chemical thinning by the use of Urea, growth substances like naphthalene acetic acid (NAA), naphthalene acetamide (NAD), 2,4-dichlorophenoxy acetic acid (2,4-D), dinitro-ortho-cresol (DNOC) etc. (Dubey et al., 2002 and Tiwari and Lal, 2007). The objective of crop regulation is to manipulate the natural flowering of the guava plant in desired season that can put in to increased fruit yield, quality and profitability. Currently, specific PGRs are used to modify crop growth rate and growth pattern during the various stages of development. In order to have a winter harvest, fruit thinning is advisable. According to Sing et al., (1996), flower thinning from guava plants during summer, improved fruit quality and increase yield during next winter. The percentage of flowering and fruiting, poor yield and quality fruits are of major concern of the fruit growers. The natural flowering and fruiting behaviour of guava are needed to be regulated, towards the production of heavy crop load during winter season to make guava cultivation highly profitable and market oriented. However, no such work has been reported under the hot and moist sub humid conditions of Western Central Table Land zone of Odisha in Eastern part of India. Keeping this in view, an investigation was carried out to evaluate the effect of different crop regulation methods and chemicals on growth, flowering and yield of Guava cv. Arka Mridula.

\section{Materials and Methods}

The study was conducted at Instructional Farm, Krishi Vigyan Kendra, Jharsuguda in Guava (Psidium guajava L.) cv. Arka Mridula during 2016-17 and 2017-18. The soil of the experimental orchard is red laterite and the climatic condition of the region is hot and moist sub humid conditions of Western Central Table Land zone of Odisha. The guava plants were procured from Central Horticultural Experiment Station, Bhubaneswar. The experiment consisted of 8 treatments $\left(\mathrm{T}_{1}\right.$ :Control, $\mathrm{T}_{2}$ : Shoot bending; $\mathrm{T}_{3}$ : $10 \mathrm{~cm}$ pruning with complete removal of old leaves, in April-May; $\mathrm{T}_{4}: 50 \%$ fruit thinning randomly by hand at an average fruit weight $15-20 \mathrm{~g}$ in April-May ; $\mathrm{T}_{5}$ : Foliar spray of Naphthalene Acetamide (NAD) @ 50 ppm 
twice at 15 days interval during April-May ; $\mathrm{T}_{6}$ : Foliar spray of $(2,4-\mathrm{D}) @ 60$ ppm, twice at 15 days interval in the during April-May; $\mathrm{T}_{7}$ : Foliar spray of urea @ 15\%, twice at 15 days interval during April-May and $\mathrm{T}_{8}$ : Foliar spray of Dinitro Ortho Cresol (DNOC) @ 10ppm, twice at 10 days during April-May). Healthy and disease free lateral shoots were selected for shoot bending with utmost care. Shoot bending was done in such a way that the bent branch did not broken down after bending. Shoots were bent at $90^{\circ}$ angle with the help of a piece of rope. Before shoot bending 3-5 leaves were kept at the upper portion of the branch to continue its photosynthesis and respiration process and rest leaves were removed off.

These 8 treatments were imposed on 4-5 years old guava plants of cultivars Arka Mridula which were maintained at a spacing of $5 \mathrm{~m} \mathrm{x}$ $5 \mathrm{~m}$. Each treatment was replicated thrice with two plants per replication. During both the years, the experimental plants were applied with $20 \mathrm{~kg}$ FYM along with 500, 200, $300 \mathrm{~g}$ of $\mathrm{N}, \mathrm{P}_{2} \mathrm{O}_{5}$ and $\mathrm{K}_{2} \mathrm{O}$. A full dose of FYM and $\mathrm{P}_{2} \mathrm{O}_{5}$ was applied at the time of imposition of treatment. Nitrogen and $\mathrm{K}_{2} \mathrm{O}$ were applied in 2 split doses. The first dose of $\mathrm{N}$ and $\mathrm{K}_{2} \mathrm{O}$ was applied along with $\mathrm{FYM}+$ $\mathrm{P}_{2} \mathrm{O}_{5}$ and the second was applied during the second week of September. The plant protection and other cultural operations were uniformly given as and when required. Observations were recorded on vegetative growth parameters like plant height, canopy spread in East-West and North-South direction, number of days required for initiation of vegetative buds, number of new shootlets / pruned shoot and other parameters like number of days required for initiation of flowers on newly emerged shoots and days required for attainment of fruit maturity, fruit weight (g), number of fruits / plant and fruit yield per plant $(\mathrm{Kg})$ etc. The data on the above parameters were subjected to analysis of variance (Panse and Sukhatme, 1989).

\section{Results and Discussion}

Growth and vigour of the trees were recorded in terms of plant height, spread in East-West and North-South direction. The growth characters of the tree were significantly influenced by different treatments.

\section{Plant height (m)}

The effect of different crop regulation intervention had a significant influence on the plant height during both years of 2016-17 and 2017-18 (Table 1). The height of guava plants after crop regulation intervention varied between $1.89 \mathrm{~m}$ to $3.18 \mathrm{~m}$. The maximum height of the plants was recorded in control $(3.18 \mathrm{~m})$ i.e. in $\mathrm{T}_{1}$ while the minimum plant height $\left(1.89 \mathrm{~m}\right.$ ) was recorded in $\mathrm{T}_{2}$ (shoot bending) followed by $(2 \mathrm{~m})$ in $\mathrm{T}_{7}$ (15\% urea). During second year (2017-18) maximum plant height was recorded in $\mathrm{T}_{1}$ i.e. control $(4.12 \mathrm{~m})$ followed by in $50 \%$ fruit thinning $(4.02 \mathrm{~m})$ treatment $\left(\mathrm{T}_{4}\right)$ whereas the shortest plant height was recorded in $\mathrm{T}_{2}$ i.e. in shoot bending $(2.01 \mathrm{~m})$ followed by $(3.17 \mathrm{~m})$ in $\mathrm{T}_{8}$ i.e. with application of $10 \mathrm{ppm}$ DNOC. However, according to Prajapati and Singh (2018) NAA (200 ppm) increased the growth parameters of guava such as plant height $(4.13 \mathrm{~m})$ followed by $\mathrm{GA}_{3}$ under Allahabad condition.From the pooled data it was established that untreated treatment (Control i.e. $\mathrm{T}_{1}$ ) resulted maximum plant height while it was recorded minimum in Bending i.e. $\mathrm{T}_{2}$. Thus, the vegetative growth of guava seems to respond to variation in different crop regulation methods (like bending, shoot pruning, fruit thining and use of chemicals). Under pruning treatments, it might shift the allocation of metabolites from rainy season crop in favour of increased vegetative growth due to flower and fruitlet removal as a result of pruning. Branch bending opens up the 
canopy and improves leaf photosynthesis by change in leaf exposure to sunlight ( $\mathrm{Li}$ and Lakso, 2004).

\section{Canopy spread (m) in East-West direction}

The data depicted in the Table 1, indicated that during both the year the canopy spread in East-West direction varied significantly. During $1^{\text {st }}$ year the maximum canopy spread $(3.43 \mathrm{~m})$ in East-West direction was recorded in $\mathrm{T}_{3}(10 \mathrm{~cm}$ pruning $)$ followed by $\mathrm{T}_{2}$ i.e. under shoot bending $(2.73 \mathrm{~m})$. The minimum E-W canopy spread was recorded in $50 \%$ fruit thinning $(1.77 \mathrm{~m})$ followed by $50 \mathrm{ppm}$ NAD $(2.01 \mathrm{~m})$. In second year canopy spread varied between $2.93 \mathrm{~m}$ to $4.54 \mathrm{~m}$. The maximum total increase in plant spread was recorded in shoot bending $(4.54 \mathrm{~m})$ which was very closely followed by $10 \mathrm{~cm}$ pruning $(4.21 \mathrm{~m})$, while lowest E-W plant spread was recorded in untreated plant $(2.93 \mathrm{~m})$, followed by $50 \%$ fruit thinning $(3.33 \mathrm{~m})$. From the pooled data, it was found highest in $\mathrm{T}_{3}$ followed by $\mathrm{T}_{2}$ and $\mathrm{T}_{5}$.

\section{Canopy spread (m) in East-West direction}

The guava plant under study showed significant variations among themselves with regards to canopy spread in North-South direction during rainy season and winter season crop of guava (Table 1). The spread of guava plants after treatments varied between 2.15 to $2.43 \mathrm{~m}$. During first year, mmaximum canopy spread in the North-South direction was recorded in the $10 \mathrm{~cm} \operatorname{pruning}(2.43 \mathrm{~m})$ followed by $(2.36 \mathrm{~m})$ under $\mathrm{T}_{6}$ i.e., $(60 \mathrm{ppm}$ 2,4-D) whereas it was recorded minimum $(2.15 \mathrm{~m})$ in $\mathrm{T}_{1}$ (Control) followed by $\mathrm{T}_{8}$ i.e. 10 ppm DNOC $(2.20 \mathrm{~m})$. During second year highest canopy spread in North-South direction was observed in $10 \mathrm{~cm}$ pruning $(3.03 \mathrm{~m})$ followed by $50 \mathrm{ppm}$ NAD $(2.98 \mathrm{~m})$ with minimum in control $(2.35 \mathrm{~m})$ followed by $\mathrm{T}_{6}(2.42 \mathrm{~m})$ i.e. with $60 \mathrm{ppm}$ 2,4-D.
From the pooled data, the canopy spread in East-West and North-South were recorded highest in $T_{3}(10 \mathrm{~cm}$ pruning). The results of pruning and thinning treatment is in line with the findings of Tiwari and Lal (1984) and Singh, (1986) who reported that pruning the current season's growth of spring flush could avoid the rainy season crop for getting a subsequent good winter crop.

The results pertaining to plant height, canopy spread (East-West and North-South direction) were in close proximity with the findings of Singh et al., (1992) and Brar (2010) who reported maximum increment in plant height, canopy spread in East-West and North-South direction with foliar application of growth regulators like $60 \mathrm{ppm}$ of 2,4-D. It might be due to immediate absorption of auxins, which increased the endogenous auxin level that resulted in cell elongation and enhanced vegetative growth.

\section{Number of days required for emergence of new shoots}

The number of days taken emergence of new shoots of guava cv. Arka Mridula was significantly influenced by different crop regulation treatments. It was quite apparent from the data depicted in the Table 2, that crop regulation treatments had profuse effect on the emergency of new shoots. It was found that except the treatments control $\left(\mathrm{T}_{1}\right)$ and $\left(\mathrm{T}_{4}\right)$ i.e. $50 \%$ fruit thinning, all other treatments caused early emergence of new shoots.

During first year, a minimum of $16.3 \& 18$ days were required for emergency of new shoots in bending $\left(\mathrm{T}_{2}\right)$ and $10 \mathrm{~cm}$ pruning $\left(\mathrm{T}_{3}\right)$ respectively which were followed by the treatment $\left(\mathrm{T}_{7}\right)$ i.e. application of $15 \%$ urea (21.7) and $\mathrm{T}_{5}$ i.e. with application of $50 \mathrm{ppm}$ NAD (27) while $\left(\mathrm{T}_{1}\right)$ control and $\left(\mathrm{T}_{4}\right) 50 \%$ thinning took maximum days for the 
emergence of new shoot, i.e.37.7 and 35.3 days respectively. During second year the treatments the same trend was obtained with minimum of (19.67 \& 20.33 days) were required for emergence of new shoots in shoot bending $\left(\mathrm{T}_{2}\right)$ and $10 \mathrm{~cm}$ pruning $\left(\mathrm{T}_{3}\right)$ respectively while it took more days (34 days) in the untreated control (T1) and 32 days in $\left(\mathrm{T}_{4}\right)$. The same trend was also obtained from the pooled data with minimum of $(18.00 \&$ 19.2 days) in shoot bending $\left(\mathrm{T}_{2}\right)$ and $10 \mathrm{~cm}$ pruning $\left(\mathrm{T}_{3}\right)$ respectively while it took more days (35.8 days) for emergence of new shoots in the untreated control $\left(\mathrm{T}_{1}\right)$ followed by 33.7 days in $\left(\mathrm{T}_{4}\right)$.

Similar effects of pruning and branch bending on shoot emergence have also been reported earlier by Sherif, (2012) in Pear. This result was also found to be in close proximity with the finding of Nandi et al., (2017) who opined that bending in summer months (March to June) resulted early emergence of new shoot (15.0 to 19.3 days) and Ghosh and Sukul (2003) who reported that summer season bending is more responsive in early emergence of new shootlets in profuse number.

\section{Number of shootlets per branch}

The number of shootlets varied significantly among different treatments with higher number in bending treatments as compared to control (Table 2). During $1^{\text {st }}$ year the maximum number of shoots per branch (14.25) was found in $\mathrm{T}_{2}$ (shoot bending) followed by (12.92) in $\mathrm{T}_{3}$ (with $10 \mathrm{~cm}$ pruning) and (12.52) in $\mathrm{T}_{5}$ (50 ppm NAD).

The minimum number of shoots per branch (9.58) was observed in $\mathrm{T}_{1}$ (control) followed by $50 \%$ thinning of fruits $\left(\mathrm{T}_{4}\right)$. During second year, it was recorded maximum with bending i.e. $\mathrm{T}_{2}$ (33.49) followed by $\mathrm{T}_{5}(29.42)$ and minimum in untreated control i.e. $\mathrm{T}_{1}(22.51)$.
From the pooled data, it was recorded maximum in $T_{2}$ (23.9) closely followed by $T_{3}$ (21.6), $\mathrm{T}_{5}$ (21.0) and $\mathrm{T}_{6}(20.2)$ and minimum in $T_{1}$ (16.0) followed by $T_{4}$ (16.8). Similar findings were obtained by Lakhpati and Rajkumar (2018) who recorded the minimum number of new shoot per pruned shoot (2.96) in control plants (untreated) than all other treatments.

\section{Duration for initiation of flowers in new shootlet}

The data pertaining to duration for initiation of flowers in new shootlet in different crop regulation treatment in guava during both the year were presented in the Table 3 . The data revealed that during first year, the shoot bending treatment $\left(\mathrm{T}_{2}\right)$ recorded early initiation of flowers (42 days) in new shootlets followed by $\mathrm{T}_{3}$ i.e. with $10 \mathrm{~cm}$ pruning (44.7 days) , whereas delayed initiation of flowers (49 days) was found in untreated control $\left(\mathrm{T}_{1}\right)$ plants in the new shootlet. During second year, it ranged between 45 days in $\left(\mathrm{T}_{2}\right)$ and 52 days in control plants $\left(\mathrm{T}_{1}\right)$. From the pooled data, it was confirmed that shoot bending $\left(\mathrm{T}_{2}\right)$ took minimum days (43.5 days) followed by $\mathrm{T}_{3}$ (45.8 days) while control plants $\left(\mathrm{T}_{1}\right)$ took maximum days (50.5 days) for initiation of flowers in the new shoots. In case of bending of branch wood pressure of branch is increased and phloem formation decreased. As a result photosynthetic product goes by slowly from the shoots of twisted branches as to the other parts, maintaining higher $\mathrm{C}: \mathrm{N}$ ratio and induce more flowering and fruit set. Bending forced dormant reproductive buds into growth. The above results are in consonance with findings of Ghosh (2003) who reported that bending of shoots increases number of flowers per plant during off-season that also supports the present experimental results. 
Table.1 Effect of different crop regulation methods and chemicals on vegetative characters of Guava cv. Arka Mridula

\begin{tabular}{|c|c|c|c|c|c|c|c|c|c|}
\hline \multirow[t]{2}{*}{ Treatments } & \multicolumn{3}{|c|}{ Plant height (m) } & \multicolumn{3}{|c|}{ Canopy spread E-W (m) } & \multicolumn{3}{|c|}{ Canopy spread N-S (m) } \\
\hline & $1^{\text {st }}$ year & $2^{\text {nd }}$ year & Pooled & $1^{\text {st }}$ year & $2^{\text {nd }}$ year & Pooled & $1^{\text {st }}$ year & $2^{\text {nd }}$ year & Pooled \\
\hline $\mathbf{T}_{1}$-Control & 3.18 & 4.12 & 3.65 & 2.19 & 2.93 & 2.4 & 2.15 & 2.35 & 2.3 \\
\hline $\mathbf{T}_{2}$-Shoot bending & 1.89 & 2.01 & 1.95 & 2.73 & 4.54 & 3.3 & 2.33 & 2.62 & 2.5 \\
\hline$T_{3}-10 \mathrm{~cm}$ pruning & 2.49 & 3.74 & 3.12 & 3.43 & 4.21 & 3.7 & 2.43 & 3.03 & 2.7 \\
\hline$T_{4}-50 \%$ fruit thinning & 2.53 & 4.02 & 3.28 & 1.77 & 3.33 & 2.3 & 2.30 & 2.60 & 2.4 \\
\hline$T_{5}-50$ ppm NAD & 2.45 & 3.21 & 2.83 & 2.01 & 4.15 & 3.1 & 2.24 & 2.98 & 2.6 \\
\hline$T_{6}-60 \mathrm{ppm} \mathrm{2,} \mathrm{4-D}$ & 2.13 & 3.19 & 2.66 & 2.65 & 3.46 & 2.4 & 2.36 & 2.42 & 2.4 \\
\hline $\mathrm{T}_{7}-15 \%$ Urea & 2.00 & 3.19 & 2.59 & 2.21 & 3.56 & 2.6 & 2.32 & 2.57 & 2.4 \\
\hline $\mathrm{T}_{8}$-10ppm DNOC & 2.03 & 3.17 & 2.60 & 2.23 & 3.38 & 2.6 & 2.20 & 2.55 & 2.4 \\
\hline S.E $(\mathbf{m})+$ & 0.33 & 0.37 & 0.20 & 0.21 & 0.21 & 0.12 & 0.09 & 0.09 & 0.05 \\
\hline CD at $(5 \%)$ & 1.00 & 1.11 & 0.60 & 0.64 & 0.64 & 0.37 & 0.27 & 0.28 & 0.16 \\
\hline
\end{tabular}

Table.2 Effect of different crop regulation methods and chemicals on days required for emergence of new shoots and number of new shootlets/ pruned shoot of Guava cv. Arka Mridula

\begin{tabular}{|c|c|c|c|c|c|c|}
\hline \multirow[t]{2}{*}{ Treatments } & \multicolumn{3}{|c|}{$\begin{array}{l}\text { Number of days required for emergence of } \\
\text { new shoots }\end{array}$} & \multicolumn{3}{|c|}{ Nos. of new shootlets /pruned shoot } \\
\hline & $1^{\text {st }}$ year & $2^{\text {nd }}$ year & Pooled & $1^{\text {st }}$ year & $2^{\text {nd }}$ year & Pooled \\
\hline $\mathbf{T}_{1}$-Control & 37.67 & 34.00 & 35.8 & 9.58 & 22.51 & 16.0 \\
\hline $\mathbf{T}_{2}$-Shoot bending & 16.33 & 19.67 & 18.0 & 14.25 & 33.49 & 23.9 \\
\hline$T_{3}-10 \mathrm{~cm}$ pruning & 18.00 & 20.33 & 19.2 & 12.92 & 30.36 & 21.6 \\
\hline $\mathrm{T}_{4}-50 \%$ fruit thinning & 35.33 & 32.00 & 33.7 & 10.02 & 23.55 & 16.8 \\
\hline$T_{5}-50$ ppm NAD & 27.00 & 30.33 & 28.7 & 12.52 & 29.42 & 21.0 \\
\hline$T_{6}-60$ ppm 2, 4-D & 29.00 & 29.00 & 29.0 & 12.05 & 28.32 & 20.2 \\
\hline$T_{7}-15 \%$ Urea & 21.67 & 24.33 & 23.0 & 11.85 & 27.85 & 19.8 \\
\hline$T_{8}-10 p p m$ DNOC & 31.33 & 31.33 & 31.3 & 10.39 & 24.42 & 17.4 \\
\hline S.E $(\mathbf{m})+$ & 1.28 & 1.24 & 0.73 & 0.04 & 0.15 & 0.06 \\
\hline CD at (5\%) & 3.89 & 3.75 & 2.18 & 0.12 & 0.45 & 0.19 \\
\hline
\end{tabular}


Table.3 Effect of different crop regulation methods and chemicals on days required for initiation of flowers and days required for fruit maturity in Guava cv. Arka Mridula

\begin{tabular}{|c|c|c|c|c|c|c|}
\hline \multirow[t]{2}{*}{ Treatments } & \multicolumn{3}{|c|}{$\begin{array}{l}\text { Number of days required for initiation of flowers } \\
\text { on newly emerged shoots }\end{array}$} & \multicolumn{3}{|c|}{$\begin{array}{l}\text { Number of days required for attainmen } \\
\text { of fruit maturity }\end{array}$} \\
\hline & $1^{\text {st }}$ year & $2^{\text {nd }}$ year & Pooled & $1^{\text {st }}$ year & $2^{\text {nd }}$ year & Pooled \\
\hline $\mathbf{T}_{1}$-Control & 49.00 & 52.00 & 50.5 & 134.33 & 134.67 & 134.5 \\
\hline $\mathbf{T}_{2}$-Shoot bending & 42.00 & 45.00 & 43.5 & 126.00 & 127.33 & 126.7 \\
\hline$T_{3}-10 \mathrm{~cm}$ pruning & 44.67 & 47.00 & 45.8 & 127.00 & 127.67 & 127.3 \\
\hline $\mathrm{T}_{4}-50 \%$ fruit thinning & 48.00 & 49.33 & 48.7 & 133.00 & 133.67 & 133.3 \\
\hline$T_{5}-50$ ppm NAD & 47.00 & 50.00 & 48.5 & 131.33 & 131.33 & 131.3 \\
\hline$T_{6}-60$ ppm 2, 4-D & 46.00 & 49.00 & 47.5 & 134.00 & 132.67 & 133.3 \\
\hline$T_{7}-15 \%$ Urea & 45.00 & 47.67 & 46.3 & 129.00 & 129.00 & 129.0 \\
\hline$T_{8}-10 p p m$ DNOC & 48.33 & 50.00 & 49.2 & 132.00 & 133.00 & 132.5 \\
\hline S.E $(\mathbf{m})+$ & 0.92 & 0.82 & 0.50 & 1.02 & 0.91 & 0.56 \\
\hline CD at (5\%) & 2.79 & 2.50 & 1.51 & 3.10 & 2.75 & 1.67 \\
\hline
\end{tabular}

Table.4 Effect of different crop regulation methods and chemicals on number of fruits/tree, fruit weight and yield of Guava cv. Arka Mridula

\begin{tabular}{|c|c|c|c|c|c|c|c|c|c|c|c|c|}
\hline \multirow[t]{2}{*}{ Treatments } & \multicolumn{3}{|c|}{ No. of fruits/tree } & \multicolumn{3}{|c|}{ Average fruit weight (g) } & \multicolumn{3}{|c|}{ Yield /tree (Kg) } & \multicolumn{3}{|c|}{ Yield per hectare (q/ha) } \\
\hline & $1^{\text {st }}$ year & $2^{\text {nd }}$ year & Pooled & $1^{\text {st }}$ year & $2^{\text {nd }}$ year & Pooled & $1^{\text {st }}$ year & $2^{\text {nd }}$ year & Pooled & $1^{\text {st }}$ year & $2^{\text {nd }}$ year & Pooled \\
\hline $\mathbf{T}_{1}$-Control & 56.16 & 60.21 & 58.19 & 104.91 & 82.36 & 88.0 & 5.89 & 4.96 & 5.43 & 23.56 & 19.84 & 21.72 \\
\hline$T_{2}$-Shoot bending & 64.50 & 71.91 & 68.20 & 115.24 & 100.69 & 104.3 & 7.43 & 7.24 & 7.34 & 29.72 & 28.96 & 29.36 \\
\hline$T_{3}-10 \mathrm{~cm}$ pruning & 58.00 & 66.00 & 62.00 & 120.67 & 132.65 & 129.7 & 7.00 & 8.75 & 7.88 & 28.00 & 35.00 & 31.52 \\
\hline $\mathrm{T}_{4}-50 \%$ fruit thinning & 56.33 & 58.35 & 57.34 & 118.96 & 127.01 & 125.0 & 6.69 & 7.41 & 7.05 & 26.76 & 29.64 & 28.20 \\
\hline$T_{5}-50$ ppm NAD & 63.19 & 69.36 & 66.28 & 121.67 & 142.79 & 133.6 & 7.70 & 9.90 & 8.80 & 30.80 & 39.60 & 35.20 \\
\hline$T_{6}-60$ ppm 2, 4-D & 59.58 & 65.87 & 62.73 & 120.20 & 126.88 & 129.2 & 7.16 & 8.36 & 7.76 & 28.64 & 33.44 & 31.04 \\
\hline$T_{7}-15 \%$ Urea & 58.00 & 59.75 & 58.87 & 114.78 & 109.45 & 110.8 & 6.65 & 6.54 & 6.60 & 26.60 & 26.16 & 26.40 \\
\hline $\mathrm{T}_{8}-10 p p m$ DNOC & 56.17 & 58.14 & 57.16 & 113.02 & 85.58 & 92.4 & 6.35 & 4.98 & 5.66 & 25.40 & 19.92 & 22.64 \\
\hline S.E (m) + & 2.25 & 1.18 & 1.23 & 2.36 & 2.01 & 1.35 & 0.25 & 0.19 & 0.14 & 1.00 & 0.83 & 2.08 \\
\hline CD at $(5 \%)$ & 4.55 & 2.38 & 2.48 & 4.77 & 4.07 & 2.74 & 0.50 & 0.39 & 0.27 & 2.02 & 1.68 & 4.20 \\
\hline
\end{tabular}


The upright branch produces fewer flowers and fruits than the bent branch (Ito et al., 1999). Among the chemicals, the treatment $T_{7}$ (15\% Urea) took minimum days (46.3) for initiation for flowering followed by 47.5 days in $\mathrm{T}_{6}(60 \mathrm{ppm} 2,4-\mathrm{D})$ and 48.5 days in $\mathrm{T}_{5}(50$ ppm NAD). This result corroborated with the finding of Maji et al., (2015) who concluded that summer deblossoming with NAD (60 ppm) was the most effective crop regulating treatment followed by NAA @ 500 ppm and Kumar and Hoda (1977) who reported that NAD (50 ppm) and 2, 4-D (30 ppm) were the most effective chemicals for deblossoming of summer flowers. By deblossoming or thinning of ambe bahar flowers, the trees produced abundant flowers in June- July and fruits were ready for harvesting in the month of October-November.

\section{Number of days required for fruit maturity}

From the data presented in the Table 3, it indicated that the treated guava showed significant variations regarding period required from flowering to fruit maturity. Shoot bending $\left(\mathrm{T}_{2}\right)$ and $10 \mathrm{~cm}$ pruning $\left(\mathrm{T}_{3}\right)$ treatment took minimum duration for fruit maturity i.e. (126 days and 127 days during first year) and (127.3 days and 127.67 days during second year) respectively. Maximum duration from flowering to fruit maturity was recorded in untreated $\left(\mathrm{T}_{1}\right)$ i.e. control plants (134.33 days and 134.67 days) during first and second year respectively. From the pooled data, it was found that the period required for fruit maturity varied from 126.7 days in bending $\left(\mathrm{T}_{2}\right)$ to 134.5 days in control plants $\left(\mathrm{T}_{1}\right)$. Further, it is inferred that among cultural methods, $\mathrm{T}_{3}(10 \mathrm{~cm}$ pruning $)$ and $\mathrm{T}_{1}$ (control) recorded minimum (127.3) and maximum (134.5) days respectively for attainment of fruit maturity. Among chemicals, the treatment $\mathrm{T}_{7}(15 \%$ Urea $)$ recorded minimum days (129) followed by 131.3days in $\mathrm{T}_{5}$ (50 ppm NAD application).

\section{Number of fruits per plant}

Data presented in Table. 3 showed that the number of harvested fruits per plant varied significantly and during first year, it ranged between 56.16 to 64.50 among the treatments. The highest number of fruits (64.50) per plant were obtained by the treatment $\mathrm{T}_{2}$ (Shoots bending) followed by $T_{5}(63.19)$ i.e. with 60 ppm NAD. The control plant $\left(\mathrm{T}_{1}\right)$ recorded the lowest number of fruits (56.16) per plant whereas the treatment $\mathrm{T}_{4}$ (50\% thinning) was statistically at par with control $\left(\mathrm{T}_{1}\right)$. During $2^{\text {nd }}$ year significant differences among the different treatment with respect to the number of fruits per plant was observed. The highest number of fruits per plant was observed in treatment $\mathrm{T}_{2}$ (71.91) followed by $\mathrm{T}_{5}$ (69.36). So with respect to the number of fruits per plant, shoot bending recorded highest number of fruits per plant during both the years and were significantly different from other treatments. Shoot bending $\left(\mathrm{T}_{2}\right)$ and $50 \mathrm{ppm}$ NAD $\left(\mathrm{T}_{5}\right)$ recorded highest number of fruits per plant during $1^{\text {st }}$ and $2^{\text {nd }}$ year respectively and were significantly different from other treatments. Both the treatments were also found significantly superior over the control. The results are in line with the findings of Singh (1986) who reported NAD (50 ppm) application was very effective in reducing rainy season crop with subsequent increased fruit set and fruit number during winter and Kumar and Hoda (1977) who suggested for application of NAD (50 ppm) and 2,4-D (30 $\mathrm{ppm}$ ) in thinning rainy season crop. Pruning also reduces tree crown area and improves number of fruits per plant in guava (Dalal et al., 2000 and Brar et al., 007).

\section{Fruit weight (g)}

The data presented in Table. 4 showed that all the treatments varied significantly. All the treatment resulted higher fruit weight over the control $\left(\mathrm{T}_{1}\right)$. During first year, it was recorded 
highest $(121.67 \mathrm{~g})$ in $\mathrm{T}_{5}(50 \mathrm{ppm}$ NAD $)$ followed by treatment with $10 \mathrm{~cm}$ pruning i.e. $\mathrm{T}_{3}$ (120.67 g), $\mathrm{T}_{6}$ (60 ppm 2, 4-D) (120.20), and 118.96 in $\mathrm{T}_{4}(50 \%$ fruit thinning) and bending i.e. $T_{2}$ (115.24) whereas it was lowest (104.91 g) in control( $\left.\mathrm{T}_{1}\right)$.However, during second year, the heaviest fruit (142.79 g) was found in $\mathrm{T}_{5}$ (50 ppm NAD) followed by (132.65 g) in $\mathrm{T}_{3}(10 \mathrm{~cm}$ pruning) while lowest fruit weight (82.36 g) was recorded in control $\left(\mathrm{T}_{1}\right)$. From the average data it was ascertained that heaviest fruit $(133.6 \mathrm{~g})$ was found in $\mathrm{T}_{5}$ (50 ppm NAD) followed by $129.7 \mathrm{~g} \mathrm{inT}_{3}(10$ $\mathrm{cm}$ pruning) and $129.2 \mathrm{~g}$ in $\mathrm{T}_{6}(60 \mathrm{ppm} \mathrm{2,4-}$ D). Lowest fruit weight was obtained in $T_{1}$ i.e. control $(88 \mathrm{~g})$. Application of growth substances like NAD (30 and $50 \mathrm{ppm}$ ) increased weight of fruit (Mitra et al., 1982). The increased fruit weight could be attributed to an increase in the size of the cells and accumulation of food substances in the intercellular spaces in fruit.Fruit weight at harvest was negatively correlated with crop load, and fruit weight was greatest when there was minimum competition between fruit (Palmer et al., 1997).

\section{Yield per plant $(\mathbf{K g})$}

The fruit yield is an ultimate factor that decides the success and failure of any technology to the fruit growers. It was implied from the data presented in the Table4, that the yield ( $\mathrm{kg} \mathrm{/} \mathrm{plant)} \mathrm{varied}$ significantly due to different treatments. During $1^{\text {st }}$ year highest yield per plant was recorded in the $50 \mathrm{ppm}$ NAD $(7.70 \mathrm{~kg})$ followed by shoot bending $(7.43 \mathrm{~kg})$, while the lowest yield per plant was recorded in control plant $(5.89 \mathrm{~kg})$ followed by treatment of $10 \mathrm{ppm}$ DNOC $(6.35 \mathrm{~kg})$. Similarly during second year the highest yield per plant $(9.90$ $\mathrm{kg}$ ) was recorded in $\mathrm{T}_{5}$ i.e.50 ppm NAD followed by $\mathrm{T}_{3}(10 \mathrm{~cm}$ pruning $)$ and $8.36 \mathrm{~kg}$ in $\mathrm{T}_{6}$ (60 ppm 2, 4-D).The treatment $\mathrm{T}_{1}$ produces the lowest yield per plant $(4.96 \mathrm{~kg})$ which was followed by $\mathrm{T}_{8}(4.98 \mathrm{~kg})$. From the mean data, it was obvious that $\mathrm{T}_{5}(50 \mathrm{ppm}$ NAD) gave highest fruit yield $(8.80 \mathrm{~kg})$ followed by $7.88 \mathrm{~kg}$ in $\mathrm{T}_{3}$ (10 $\mathrm{cm}$ pruning), $7.76 \mathrm{~kg}$ in $\mathrm{T}_{6}(60 \mathrm{ppm} 2,4-\mathrm{D})$ and $7.34 \mathrm{~kg}$ in $\mathrm{T}_{2}$ (Bending) whereas it was recorded lowest in control (5.43 kg/plant). So it was clear that with respect to the yield per plant the all treatments were found superior to the check. However, according to Bagchi et al. (2008), bending of shoots gave the highest yield per plant $(48.6 \mathrm{~kg} /$ plant), followed by $20 \mathrm{~cm}$ pruning (23 kg /plant). The result are close proximity with e research results of (Mamun et al., 2012) who obtained highest fruit yield $(13.50 \mathrm{~kg} /$ plant $)$ in shoot bending treatment and the lowest fruit yield $(7.19 \mathrm{~kg} /$ plant $)$ was recorded in $100 \%$ fruit thinning treatment and (Sarker et al., 2005), who reported that shoot bending increased the fruit yield per plant and quality fruit during off season.

\section{Yield per hectare (q/ha)}

Yield characteristics have been found significantly affected by various treatments. From the data depicted in the Table-4, the yield per hectare in $1^{\text {st }}$ year varied from a minimum of $23.56(\mathrm{q} / \mathrm{ha})$ in control $\left(\mathrm{T}_{1}\right)$ to a maximum of $30.80 \mathrm{(q} / \mathrm{ha})$ in $\mathrm{T}_{5}(50 \mathrm{ppm}$ NAD). The highest yield (30.80 q/ha) was noticed in $50 \mathrm{ppm}$ NAD $\left(\mathrm{T}_{5}\right)$ followed by (29.72 $\mathrm{q} / \mathrm{ha}$ ) in $\mathrm{T}_{2}$ (shoot bending), (28.65 $\mathrm{q} / \mathrm{ha})$ in $\mathrm{T}_{6}(60 \mathrm{ppm} 2,4-\mathrm{D})$ and ( $\left.28 \mathrm{q} / \mathrm{ha}\right)$ in $\mathrm{T}_{3}$ (10 $\mathrm{cm}$ pruning). The lowest yield (23.56 $\mathrm{q} / \mathrm{ha}$ ) was observed in control $\left(\mathrm{T}_{1}\right)$ followed by $(25.40 \mathrm{q} / \mathrm{ha})$ in $\mathrm{T}_{8}(10 \mathrm{ppm}$ DNOC $)$, and $26.60 \mathrm{q} / \mathrm{ha}$ in $\mathrm{T}_{7}(15 \%$ urea $)$.

Similarly during second year the highest yield per hectare $(39.60 \mathrm{q} / \mathrm{ha})$ was recorded in $\mathrm{T}_{5}\left(50 \mathrm{ppm}\right.$ NAD) followed by $\mathrm{T}_{3}(35.00 \mathrm{q} / \mathrm{ha})$ and $33.44 \mathrm{q} / \mathrm{ha}$ in $\mathrm{T}_{6}(60 \mathrm{ppm} \mathrm{2,4-D)}$ and $28.96 \mathrm{q} / \mathrm{ha}$ in $\mathrm{T}_{2}$ (Bending). The treatment $\mathrm{T}_{1}$ i.e. control produces the lowest yield per plant (19.84 q/ha).From the average data, it was 
recorded highest $(35.20 \mathrm{q} / \mathrm{ha})$ in $\mathrm{T}_{5}(50 \mathrm{ppm}$ NAD) followed by $31.52 \mathrm{q} / \mathrm{ha}$ in $\mathrm{T}_{3}(10 \mathrm{~cm}$ prunung), $31.04 \mathrm{q} / \mathrm{ha}$ in $\mathrm{T}_{6}(31.41 \mathrm{q} / \mathrm{ha})$ and $\mathrm{T}_{2}$ i.e. Bending (29.36 q/ha). The lowest yield $(21.72 \mathrm{q} / \mathrm{ha})$ was recorded in control $\left(\mathrm{T}_{1}\right)$. So with respect to the yield per hectare during both the years' different treatments shown superiority over the control. A spray of NAA (80 or $100 \mathrm{ppm}$ ) was recommended by Rathore (1975) to reduce the rainy season yield so as to increase that in the winter NAD (50 ppm) followed by 2, 4-0 (30 ppm) gave better results (Kumar and Hoda,1977). Similarly, Pandey et al. (1980) obtained maximum yield in winter season by deblossoming with 800 ppm NAA followed by 600 ppm NAA.

In conclusion the normal flowering and fruiting behaviour of guava needed to be regulated, towards the production of heavy crop load during winter season to make guava cultivation highly profitable and market oriented. In general, all the crop regulation practices were found superior over the untreated control with respect to growth, flowering yield. If the guava tree is left unpruned, they tend to prolong the vegetative growth, reduce the bearing area, thus leading to decrease in fruit size, yield and quality. Hence, to get a good balance between the vegetative and reproductive growth, pruning becomes essential. Shifting of rainy season crop to winter months in guava with the help of crop regulation method was found to be efficient method of getting a good crop producing quality fruits free from pest and diseases. Hence, the above treatment may be effectively used for commercial exploitation of guava in winter months for getting remunerative price by producing more number of quality fruits. Among the cultural treatments, the treatment $\mathrm{T}_{2}$ (Bending) was found superior to $T_{3}(10 \mathrm{~cm}$ pruning $)$ and $T_{1}$ (control). Among chemical treatments, the treatment $\mathrm{T}_{5}(50 \mathrm{ppm}$ NAD) was found superior to others $\mathrm{T}_{6}(60 \mathrm{ppm} 2,4-\mathrm{D})$ with respect to yield and other parameters studied.

\section{References}

Anonymous (2017). Department of Agriculture cooperation and farmer's welfare. http: $/ / w w w . a g r i c o o p . n i c . i n$.

Bagchi, T.B., Sukul, P. and Ghosh, B. (2008). Biochemical changes during off-season flowering in guava (Psidium guajava L.) induced by bending and pruning. J.Trop.Agric., 46 (1-2): 64-66.

Brar,J.S., Thakur,A and Arora, K.(2007).Effect of pruning intensity on fruit yield and quality of guava (Psidium guajava L.) cv. Sardar. Haryana J of Hort. Sci. 2007; 36(1-2):6566.

Brar, J.S. (2010). Influence of Paclobutrazol and Ethephon on vegetative growth of Guava (Psidium guajava L.) plants at different spacing. National Sci. Biol., 2:110-113.

Choudhury, R., Singh, U.P., Sharma, R.K., (1997). Deblossoming of rainy season crop of guava. Hort. J., 10 (1): 93-95.

Chundawat, B.S., Gupta, O.P. and Godara, N.R. (1975). Crop regulation in Banarsi Surkha guava cultivar. Haryana J.Hort. Sci., 4: 23.

Dalal,S.R, Golliwar VJ, Patil SR, Khobragade RI, Dalal NR. (2000). Effect of severity of pruning on growth, yield and quality of fruits of 25 year old guava cv. Sardar. $J$ of Soils and Crops.,10(2):298-300.

Dubey, A.K., Singh, D.B., Dubey, N., 2002. Crop regulation in guava (Psidium guajava L.) cv. Allahabad Safeda. Prog. Hort., 34 (2), 200-203.

Ghosh, B. (2003). Progress report of NATP on "Off-season flower of guava". Faculty of Horticulture, BCKV, Mohonpur, Nadia, West Bengal.pp.3-5.

Ghosh, B. and Sukul, P. (2003). Off season flowering in guava. In: Validation of Indigenous Technical Knowledge in Agriculture, Document-3. Mission Unit, Division of Agricultural Extension. ICAR, New Delhi, 220-226.

Gorakh, S. and Reddy, Y.T.N. (1997). Regulation of cropping in guava. Indian J. Hort., 54 
(1): 44- 49.

Gupta, S.N. (2014). Instant horticulture. Jain brothers, New Delhi, p. 206.

Ito, A.; Yaegaki, H.; Hayama, H.; Kusaba, S.; Yamaguchi, I. and Yoshioka, H. (1999). Bending shoots stimulates flowering and influences hormone levels in lateral buds o Japanese pear. Hort. Sci., 34: 1224 1228.

Kumar, R. and Hada, M.N. (1977). Crop regulation studies in Allahabad Safeda guava. Indian J. Hort., 34(1): 13.

Mamun, A. A., Rahman, M. H. and Rahim, M. A. (2012). Effect of Shoot Bending and Fruit Thinning on Productivity of Guava (2012). J. Environ. Sci. \& Natural Res., 5(2): $167-172$.

Mitra, S.K., Sen, S.K., Maity, S.C. and Bose, T.K.(1982). Effect of growth substances on deblossoming, regulation of cropping and fruit quality in guava. The Hort. J., 1: 81-88.

Kumar, R. and Hoda, M. N. (1977). Crop regulation studies in Allahabad Safeda guava. Indian J. Hort., 34: 13.

Lakpathi,G. and Rajkumar, M. (2018)Effect of Pruning Intensities and Fruit Load on Yield and Quality of Guava under High Density Planting System. Int.J.Curr.Microbiol.App.Sci., 7(5): 18531860

Li, K. T. and Lakso, A. N. (2004). Photosynthetic characteristics of apple spur leaves after summer pruning to improve exposure to light. Hort.Sci.,39: 969-972.

Maji S, Das BC and Sarkar SK 2015. Efficiency of some chemicals on crop regulation of Sardar guava. Scientia Hort., 188: 66-70.

Nandi, P., Roy, D., Ghosh, B and Kundu, S. (2017). Effect of bending of shoots on flowering, yield and quality of guava cv. Khaja. J. Applied and Natural Sci., 9 (3): $1365-1368$
Panse, V.C. and Sukhatme, P.V.(1989). Statistical methods for Agricultural workers. Indian Council of Agricultural Research, New Delhi, pp. 199-210.

Prajapati, M. and Singh, D. (2018). Effect of Plant Growth Regulators on Flowering, Fruit Growth and Quality of Guava (Psidium guajava L.). cv. Allahabad Safeda. Int.J.Curr.Microbiol.App.Sci.,Special Issue-7: 3355-3361.

Rathore, D.S. (1975). Deblossoming of rainy season crop of guava by NAA. Prog. Hort., 7(3): 63-65.

Sahoo, J. and Tarai, R.K.(2018). Comparative study on performance of guava genotypes during rainy and winter season under Bhubaneswar condition. Indian J. Hort., 75 (4): 554-559.

Sarkar, A., Ghosh, B., Kundu, S. and Sukul, P. (2005). Effect of shoot pruning and bending on yield and fruit quality in guava cv. L-49. Env. and Ecol., 23(3): 621-623.

Sherif, H. M. (2012). Effect of bending date on spur formation and fruit set of Le-Cote pear trees. World Rural Observations, 4 (4): $82-87$

Singh, U. P. (1986). Crop regulation studies in guava. Ph. D. thesis, RAU, Pusa Bihar Agriculture College Sabour, Bihar.

Singh, R.; Singh, S.N.; Gupta, M.R. and Dhaliwal, G.S. (1992) Studies of winter cropping in guava cv. 'Allahabad Safeda'. Indian J.Hort. 49: 127-133.

Tiwari, J. P. and Lal, S (1984). Research Report. ICAR Workshop on Fruit Research, Lucknow.

Tiwari, J.P., Lal, S. (2007). Effect of NAA, flower bud thinning and pruning on crop regulation in guava (Psidium guajava L.) cv. Sardar. Acta Hort., 735: 311-314.

\section{How to cite this article:}

Mishra, P., G. Mandal and Tarai, R. K. 2020. Effect of Different Crop Regulation Methods and Chemicals on Growth, Flowering and Yield of Guava cv. Arka Mridula. Int.J.Curr.Microbiol.App.Sci. 9(12): 649-659. doi: https://doi.org/10.20546/ijcmas.2020.912.078 